\title{
Penyesuaian Setting Ruang Untuk Bekerja Dari Rumah pada Masa Pandemi Covid-19
}

\author{
Ivada Ariyani \\ Institut Seni Indonesia Yogyakarta
}

\begin{abstract}
Abstrak
Penelitian ini bertujuan untuk menguraikan penyesuaian yang dilakukan terhadap setting ruang di dalam rumah untuk mengakomodasi kebutuhan Bekerja Dari Rumah (BDR), serta untuk mengetahui setting ruang seperti apa yang mampu mengakomodir kegiatan BDR dengan optimal di situasi darurat. Penelitian kualitatif ini dilakukan terhadap para pekerja white collar yang sebelumnya bekerja secara normal di kantor konvensional yang karena kebijakan BDR harus bekerja dari rumah. Penelitian kualitatif ini menggunakan metode photovoice, yaitu sebuah pendekatan yang melibatkan fotografi dan kegiatan partisipatori. Penelitian kualitatif ini telah mampu menjawab pertanyaan penelitian tentang bagaimana penyesuaian yang dilakukan para pekerja terhadap setting ruang di dalam rumah untuk mengakomodasi kebutuhan work from home. Dalam situasi pandemi di awal penerapan WFH, para pekerja cenderung menciptakan ruangruang majemuk dengan mengintegrasikan beragam fungsi dalam satu ruang. Ditemukan juga fakta bahwa terjadi perubahan setting ruang dalam berbagai tingkatan, yang secara umum dilakukan pada perubahan fitur semi tetap. Perubahan setting maupun dinamika pergerakan penghuni di dalam rumah tinggal juga dipengaruhi oleh kebutuhan citra ruang dalam menjalin relasi sosial melalui daring di saat pandemi. Secara umum, hal paling dibutuhkan dalam bekerja dari rumah di situasi krisis ini adalah ketiadaan beragam gangguan / distraksi. Namun seiring waktu, hal yang ditengarai penting bagi kelangsungan bekerja dari rumah adalah atmosfer rumah tinggal yang mendukung. Sirkulasi udara alami, akses terhadap view di luar serta atmosfer yang membebaskan dari rasa bosan dan perasaan terkungkung adalah faktor-faktor yang sangat penting dalam menyediakan ruang kerja di rumah di saat pandemi.
\end{abstract}

Kata kunci: setting ruang, bekerja dari rumah, penyesuaian, pandemi, Covid-19

\begin{abstract}
This study aims to describe the adjustments made to space settings in the house to accommodate the needs of Work From Home (WFH), as well as to find out what kind of room settings can accommodate BDR activities optimally in an emergency situation. This qualitative research was conducted on white collar workers who previously worked normally in conventional offices who because of WFH policies had to work from home. This qualitative research uses the photovoice method, which is an approach that involves photography and participatory activities. This qualitative research has been able to answer research questions about how workers make adjustments to space settings in the house to accommodate work from home needs. In a pandemic situation at the beginning of the implementation of WFH, workers tended to create multiple spaces by integrating various functions in one space. It was also found that there were changes in spatial settings in various levels, which generally occurred in changes to semi-fixed features. Changes in settings and the dynamics of the movement of residents in their homes are also influenced by the need for spatial images in establishing social relations online during a pandemic. In general, what is most needed in working from home in this crisis situation is the absence of various distractions. However, over time, what was seen as important for the continuity of working from home was a supportive home atmosphere. Natural air circulation, access to outside views and an atmosphere that frees from boredom and feelings of confinement are very important factors in providing work space at home during a pandemic.
\end{abstract}

Keywords: room setting, working from home, adjustment, pandemic, Covid-19 


\section{Pendahuluan}

Pandemi Covid-19 banyak merubah cara hidup manusia secara mendadak, termasuk dalam bekerja. Kebijakan pemerintah yang mendorong masyarakat untuk tetap beraktifitas dari dalam rumah menjadikan kegiatan normal keseharian mengalami perubahan yang signifikan. Aktifitas bekerja yang biasanya difasilitasi secara lengkap dalam area kerja, dalam situasi pandemi harus dilakukan dari dalam rumah dengan fasilitas yang secara mendadak harus memenuhi kegiatan dan aktifitas tersebut. Perubahan aktifitas secara tiba - tiba dalam sebuah rumah tinggal berpengaruh terhadap perubahan kebutuhan ruang dan pendukungnya. Apalagi secara umum, rumah tinggal di Indonesia hanya mewadahi fungsi - fungsi ruang yang dianggap vital seperti ruang tidur, dapur, kamar mandi, dan ruang tamu. Ruang yang secara khusus diperuntukkan bagi kegiatan bekerja sangat jarang disediakan, meskipun sebuah ruang bisa menjadi sangat cair dan fleksibel untuk memenuhi kebutuhan aktifitas lain.

Pandemi yang belum diketahui kapan akan berakhir memberi kemungkinan yang besar untuk masyarakat akan bekerja dari dalam rumah dalam jangka waktu yang juga belum bisa dipastikan. Jika di waktu awal pandemi orang menciptakan area bekerja dalam situasi yang sementara, besar kemungkinan di waktu mendatang orang yang bekerja dari rumah dalam situasi pandemi akan berusaha menciptakan area kerja yang lebih permanen. Dengan demikian akan ada penyesuaian tata ruang di dalam rumah. Dalam situasi normal, ada banyak literatur yang dapat menjadi acuan bagaimana mendesain area kerja di dalam rumah. Tetapi dalam situasi kritis seperti pandemi Covid-19 ini, dimana orang - orang harus secara tiba - tiba bekerja dari rumah, menyetting area bekerja menjadi situasi yang tidak ideal. Meski dalam skala kecil dan dilakukan oleh orang yang tidak berlatarbelakang desain, penataan sebuah ruang biasanya dilakukan dengan perencanaan, baik secara sederhana maupun dengan penuh perhitungan. Namun dalam situasi pandemi, dapat diasumsikan penataan area baru dalam rumah dilakukan dengan perencanaan yang cepat dan sederhana, iteratif, atau bahkan tidak sama sekali.

Penelitian ini perlu dilakukan mengingat bahwa meskipun dalam situasi pandemi, segala aktifitas terutama aktifitas pendukung perekonomian keluarga maupun negara harus terus berjalan. Bekerja adalah salah satu mesin penting pendorong perekonomian. Bekerja dalam situasi yang penuh keterbatasan dalam masa pandemi memerlukan dukungan lingkungan yang mengarah kepada situasi yang positif dan mendukung orang dalam bekerja. Penelitian ini menggali bagaimana penyesuaian yang dilakukan dalam rumah tinggal, serta mengetahui kendala serta permasalahan yang timbul. Penelitian ini tidak akan sampai kepada solusi desain ruang kerja dalam rumah tinggal, tetapi diharapkan dapat menguraikan ruang - ruang yang optimal untuk mengakomodir kegiatan BDR dalam situasi kritis. Lebih jauh, dalam penelitian lanjutan dimungkinkan untuk dapat memberikan celah rekomendasi maupun konsep - konsep ruang kerja dalam situasi yang tidak ideal.

Bekerja Dari Rumah (BDR) terbukti telah memberikan dampak positif maupun negatif bagi para pekerja. Mustajab dkk (2020) telah melakukan penelitian kualitatif terhadap 50 pekerja di Indonesia yang karena terdampak pandemi covid-19 harus bekerja dari rumah. Dari hasil penelitiannya, ia menyatakan bahwa BDR telah mengakibatkan menurunnya produktifitas kerja.. Melakukan beberapa pekerjaan dalam satu waktu (multitasking), kurangnya fasilitas, banyaknya gangguan, serta terbatasnya kehidupan sosial merupakan beberapa hal yang menjadi sebab rendahnya produktifitas BDR. Namun demikian, penelitian dari Ohio University membuktikan bahwa $56 \%$ pekerja menganggap bahwa bekerja dari rumah memiliki tingkat produktifitas yang sama dengan pekerjaan yang dilakukan dari kantor. Sementara, 24\% berpendapat bahwa bekerja dari rumah justru lebih meningkatkan produktifitas kerja dibandingkan bekerja di kantor (Ohio University, 2015). Beberapa hal yang menjadi kekuatan bekerja jarak jauh diantaranya adalah peningkatan produktifitas dan kualitas kerja, pengurangan ruang kantor, perasaan nyaman berada di rumah, dan dapat bekerja dengan lebih sedikit gangguan (Jackson dkk, 1998 dalam Mungkasa, 2020). 
Salah satu pokok persoalan terkait BDR adalah ketersediaan sarana bekerja dari rumah. Korte (1996) menyatakan bahwa tingkat keberhasilan BDR harus didukung oleh pemisahan urusan privasi pekerjaan dan keterkaitan dengan situasi urusan domestik. Untuk mendukung keberhasilan ini perlu didukung dengan pemisahan ruang kerja serta adanya jaminan terjaganya isu rahasia perusahaan. Hal ini terkonfirmasi oleh penelitian yang dilakukan oleh Felstead dan Jewson pada tahun 1996, bahwa pekerja dari rumah menghadapi sejumlah masalah dan gangguan spesifik yang harus dihadapi karena harus bekerja dan tinggal di ruang yang sama.

Hal ini sejalan dengan yang disampaikan Mungkasa (2020) bahwa tidak tersedianya ruang dan suasana yang mendukung untuk bekerja dari rumah serta kurangnya perangkat dan dukungan teknis menjadi hal yang dianggap sebagai tantangan bagi para pekerja. Selain itu, hal lain adalah perasaan terkungkung, kehilangan suasana berkelompok, isu keamanan data dan informasi kantor, duplikasi peralatan kerja di rumah dan di kantor (Jackson dkk, 1998 dalam Mungkasa, 2020). Pekerja yang bekerja dari rumah juga harus menghadapi isu kesehatan, yang pada penelitian yang dilakukan oleh Felstead dan Jewson (1996:96) responden menghubungkan isu kesehatan ini dengan workstation yang didesain dengan buruk.

Berdasar penelitian terhadap pekerja jarak jauh di India dan Mesir, pekerja merasakan adanya keterbatasan ruang kerja, kurangnya ketenangan dan kenyamanan, kurangnya interaksi sosial serta kekhawatiran terhadap keamanan informasi perusahaan (Hadi dan Winarno 2017, dalam Mungkasa, 2020). Di Jepang, ukuran rumah yang relatif kecil mengakibatkan sulitnya penerapan bekerja dari rumah karena tidak ada ruang khusus untuk bekerja (Higa dan Wijayanayake, 1998 dalam Mungkasa, 2020). Sementara itu, di Indonesia menurut Mungkasa (2020), gangguan domestik menjadi sumber gangguan ketika bekerja, terutama luasan rumah yang terbatas sehingga tidak memungkinkan tersedianya ruang khusus untuk bekerja.

Teori tentang sistem setting yang diutarakan oleh Rapoport penting untuk dituliskan disini, terutama karena dalam penyesuaian setting ruang untuk Bekerja Dari Rumah dimungkinkan terjadi perubahan aktifitas di dalam ruang. Setting adalah sebuah lingkungan yang mendefinisikan suatu situasi, mengingatkan penghuni akan aturan-aturan yang sesuai dan menyebabkan perilaku berkelanjutan yang sesuai dengan situasi yang ditentukan oleh setting. Setting seringkali menyediakan peralatan yang sesuai untuk perilaku dan aktifitas terkait. Situasi, aturan dan perilaku yang sesuai dan berkelanjutan dalam sebuah setting dikomunikasikan dengan tanda/ isyarat. Ini menunjukkan bahwa aktivitas dan setting dihubungkan melalui makna (Rapoport, 1990 : 13). Dengan demikian, adalah penting untuk mengonseptualisasikan lingkungan yang terdiri dari beberapa elemen fitur. Rapoport (1990 : 13) membagi elemen fitur dalam sebuah setting menjadi tiga, yaitu elemen fitur tetap (bangunan, lantai, dinding), elemen fitur semi-tetap (perabot, interior dan eksterior), dan elemen fitur tidak tetap (orang dan aktivitas dan perilaku). Perilaku yang dituntun oleh setting tidak hanya ditimbulkan melalui elemen fitur semi-tetap, tetapi isyarat yang paling penting adalah orang lain yang hadir dan aktivitas serta perilaku mereka. Dengan demikian, ruang yang sama juga bisa menjadi setting yang berbeda melalui perubahan dalam elemen fitur semi-tetap dan beragam aktivitas penghuninya.

Felstead dan Jewson (1999 : 147) membagi 4 kategori strategi pengaturan batas temporal dan spasial di dalam dan di sekitar rumah, yaitu open, closed, segregation dan integration. Open menjelaskan tentang lemahnya batas eksternal antara rumah dan dunia luar, sementara closed menunjukkan adanya batas eksternal yang kuat antara keduanya. Segregation mensyaratkan penetapan batas yang jelas antara ruang dan waktu yang dialokasikan untuk pekerjaan dan kehidupan tumah tangga. Segregation biasanya mencakup penetapan jam kerja yang jelas serta ruang kerja yang dirancang secara khusus. Integration melibatkan percampuran atas ruang dan waktu untuk pekerjaan dan aktifitas rumah tangga. M. Anderson dkk (1994) dalam Felstead dan Jewson (1999 : 148) menyatakan bahwa yang dimaksud strategi disini adalah bukan semata menyiratkan perencanaan yang disengaja dan niat yang direncanakan sebelumnya. Melainkan, strategi ini dimaksudkan untuk mendapatkan pola yang muncul, apakah pola semacam itu adalah hasil dari perencanaan yang disengaja, ataupun muncul secara kumulatif dan tidak reflektif. 
Dalam situasi krisis (pandemi Covid-19) dimungkinkan terjadi improvisasi dalam melakukan penyesuaian setting ruang. Menurut Weick (1998) improvisasi sebagai sebuah kata benda adalah transformasi dari beberapa model asli. Sementara itu, jika dianggap sebagai kata kerja, improvisasi adalah susunan secara real time yang dimulai dengan embelishment sederhana, namun kemudian seiring memakai embelishment ini, terjadi komposisi baru. Miner dkk (2001) membagi improvisasi menjadi 3 kategori yaitu "improvisasi artifaktual," di mana hasilnya adalah alat atau objek; "Improvisasi perilaku," di mana hasilnya adalah proses baru dari serangkaian tindakan; dan "improvisasi interpretatif", di mana produk merupakan cara baru untuk memahami kebutuhan, kewajiban, atau kondisi. Sementara itu, Kendra dan Watchtendorf (2007 : 326) merumuskan 3 tipologi improvisasi, yaitu reproduktif, adaptif dan kreatif. Dalam improvisasi reproduktif, improvisasi menciptakan kembali kapasitas yang ada; dalam improvisasi adaptif, mereka mengubah kapasitas yang ada untuk menyesuaikan tuntutan yang berubah, menghasilkan sistem baru. Dalam improvisasi kreatif, mereka menciptakan kapasitas yang sama sekali baru tanpa adanya model yang ada. Semua formula ini terjadi di bawah kendala waktu yang ketat dan dengan tuntutan mendesak untuk bertindak.

\section{Metode}

Penelitian kualitatif ini menggunakan metode photovoice, yaitu sebuah pendekatan metode yang melibatkan fotografi dan kegiatan partisipatori. Secara umum, photovoice digunakan dengan luas di berbagai disiplin ilmu seperti kesehatan, sosial, serta bidang ilmu yang melibatkan pekerja sosial dan kaum marginal. Langkah pertama dalam pengumpulan data ini adalah dengan cara meminta responden untuk memfoto area kerja di rumah mereka. Ini adalah cara yang digunakan dalam metode photovoice, dimana foto dijadikan alat untuk menyuarakan situasi yang dihadapi oleh responden. Responden mengirimkan 3-4 atau lebih frame foto area kerja melalui email / whatsapp kepada peneliti, sebagai bahan diskusi dalam wawancara. Langkah selanjutnya adalah melakukan wawancara melalui aplikasi zoom dengan menayangkan foto tersebut. Dalam situasi ideal, wawancara dilakukan secara langsung, untuk mendiskusikan foto tersebut. Tetapi dalam situasi pandemi, wawancara menggunakan aplikasi zoom merupakan cara alternative tanpa mengurangi kualitas hasil wawancara. Secara umum wawancara dilakukan berdasar foto kiriman dari responden, dan membiarkan responden bercerita secara mengalir tentang area kerjanya. Hal ini berdasarkan apa yang dilakukan dalam metode photovoice, dimana foto menjadi alat untuk menceritakan kejadian terkait foto tersebut, dalam hal ini area kerja di masa pandemi. Peneliti memberikan ruang yang luas bagi responden untuk menceritakan situasi yang dialami, perubahan ruang yang terjadi selama pandemi, maupun hal lain yang memperkaya data.

Responden dalam penelitian ini berjumlah 9 orang, seluruhnya bekerja secara konvensional dari kantor sebelum pandemi, dan harus bekerja dari rumah selama pandemi. Sebagian besar responden mulai WFH di akhir Maret, dan 4 orang di antaranya bekerja kembali dari kantor mulai Juni meskipun kembali bekerja dari rumah di beberapa waktu selama Juli - Agustus. Sebanyak 5 orang responden relatif bekerja dari rumah secara penuh dari Maret - Agustus dengan variasi beberapa kali kunjungan ke kantor. Hampir 90 persen seluruh responden memiliki pasangan yang bekerja, hampir seluruhnya bekerja dari rumah selama pandemi. Seluruh responden juga masih memiliki anak usia Sekolah Dasar, yang seluruhnya bersekolah dari rumah. Seluruh responden berada di jenjang middle carrier dengan rentang usia $32-43$ tahun, 3 laki - laki dan 5 perempuan. 5 di antara pekerja tersebut adalah Pegawai Negeri Sipil, 3 pegawai swasta dan 1 pegawai BUMN. Pengumpulan data dilakukan dengan wawancara melalui aplikasi zoom, dengan menggunakan fitur share screen untuk menampilkan foto yang sebelumnya dikirimkan oleh responden. Dari foto yang ditampilkan di layar masing - masing, peneliti melakukan wawancara kepada responden berdasar foto tersebut. Peneliti cenderung memberikan keleluasaan kepada responden untuk bercerita tentang situasi yang ada di dalam foto tersebut. 
Tabel 1. Profil Responden

\begin{tabular}{|l|l|l|l|l|l|}
\hline No. & Nama & Gender & Umur & Pekerjaan & Pasangan \\
\hline 01. & Responden 01 & $\mathrm{P}$ & 42 & Dosen / PNS & WFO \\
02. & Responden 02 & $\mathrm{P}$ & 32 & Analis Pajak / PNS & WFH \\
03. & Responden 03 & $\mathrm{L}$ & 43 & Manajer / Swasta & - \\
04. & Responden 04 & $\mathrm{P}$ & 35 & Analis Diklat / PNS & WFH \\
05. & Responden 05 & $\mathrm{L}$ & 43 & Analis Ekonomi / BUMN & WFO \\
06. & Responden 06 & $\mathrm{P}$ & 40 & Staf Humas / PNS & WFH \\
07. & Responden 07 & $\mathrm{P}$ & 40 & Desainer Grafis / Swasta & WFH \\
08. & Responden 08 & $\mathrm{L}$ & 43 & Event Manager / Swasta & WFH \\
09. & Responden 09 & $\mathrm{P}$ & 43 & Dosen / PNS & WFH/WFO \\
\hline
\end{tabular}

Setelah seluruh wawancara dilakukan, data yang terkumpul kemudian dikelompokkan berdasarkan kode yang muncul dalam setiap wawancara, atau disebut coding. Coding tersebut kemudian dikelompokkan menjadi tema. Dalam penelitian ini timbul beberapa tema yang akan dibahas di bawah ini.

Tabel 2. Coding Data

\begin{tabular}{|c|c|c|c|c|c|}
\hline Initial Coding & Focused Coding & Thematic Coding & Intilal Coding & Focused Coding & Thematic Coding \\
\hline ruang beragam aktifitas & \multirow{3}{*}{ ruang majemuk } & \multirow{13}{*}{ integrasi fungsi ruang } & pindah pe rabot & \multirow{8}{*}{ perabot } & \multirow{20}{*}{$\begin{array}{l}\text { Perubahan } \\
\text { Fitur Semi Tetap }\end{array}$} \\
\hline berbagi ruang & & & ganti perabot & & \\
\hline perabot beragam fungsi & & & mobile furniture & & \\
\hline gangguan kebisingan & \multirow{5}{*}{ distraksi } & & adjustable furniture & & \\
\hline berpindah ruang & & & merubah layout & & \\
\hline jalur sirkulasi utama & & & bricolage & & \\
\hline pekerjaan domestik & & & ganti fungsi perabot & & \\
\hline distraksi untuk break & & & perabot baru & & \\
\hline SFH & & & kabel LAN & \multirow{4}{*}{ equipment \& utilitas } & \\
\hline pembagian waktu & \multirow{5}{*}{ pekerjaan domestik } & & wifi & & \\
\hline pembagian tempat & & & adjustable camera & & \\
\hline mengasuh anak \& SFH & & & proper background & & \\
\hline equipment untuk WFH \& SFH & & & lesehan & \multirow[t]{2}{*}{ ergonomi } & \\
\hline breastfeeding & & & \begin{tabular}{|l|} 
perabot seadanya \\
\end{tabular} & & \\
\hline saling terganggu & \multirow{14}{*}{ nomaden } & \multirow{23}{*}{$\begin{array}{l}\text { Kompromi dan Dinamika } \\
\text { Pengguna Ruang }\end{array}$} & barang penanda & \multirow[t]{2}{*}{ teritorial } & \\
\hline mencari background & & & perabot penanda & & \\
\hline bosan & & & hindari personalisasi & \multirow[t]{2}{*}{ personalisasi } & \\
\hline tidak fokus & & & personalisasi background & & \\
\hline area kerja sementara & & & \begin{tabular}{|l|} 
dedicated room \\
\end{tabular} & \multirow[t]{2}{*}{ dedicated room } & \\
\hline tidak ergonomis & & & prime space & & \\
\hline merasa terkungkung & & & perbedaan tingkat privasi & \multirow{5}{*}{ privasi daring } & \multirow{14}{*}{$\begin{array}{l}\text { Background sebagai } \\
\text { Relasi Sosial }\end{array}$} \\
\hline tidak ada pema ndangan & & & jaga jarak & & \\
\hline cari equipment & & & aktualisasi profesi & & \\
\hline cari wifi & & & \begin{tabular}{|l} 
aktualisasi publik \\
\end{tabular} & & \\
\hline cari privasi & & & ruang instagramable & & \\
\hline berbagi ruang & & & \begin{tabular}{|l} 
background sesuai audience \\
\end{tabular} & \multirow{9}{*}{ background daring } & \\
\hline menghindari kebisingan & & & rekayasa latar belakang & & \\
\hline menghindari distraksi & & & background penting & & \\
\hline rapat daring bersamaan & \multirow{5}{*}{ konflik } & & background tidak penting & & \\
\hline gangguan kebisingan & & & penampilan sosial & & \\
\hline ruang majemuk & & & eksistensi pada atasan & & \\
\hline akuisisi ruang kerja & & & eksistensi pada bawahan & & \\
\hline menyingkir & & & \begin{tabular}{|l|} 
eksistensi pada kolega \\
\end{tabular} & & \\
\hline pasangan WFO & \multirow{4}{*}{ jadwal pemakaian ruang } & & citra & & \\
\hline dedicated room & & & pemanda ngan hijau & \multirow{6}{*}{ atmosfer } & \multirow{12}{*}{ Preferensi area kerja } \\
\hline meminjam ruang & & & hiburan & & \\
\hline saat tidak dipakai & & & break & & \\
\hline & & & refreshing & & \\
\hline & & & \begin{tabular}{|l|} 
ganti suasana \\
\end{tabular} & & \\
\hline & & & santai & & \\
\hline & & & udara segar & \multirow{3}{*}{ tata kondisional } & \\
\hline & & & pencahayaan alami & & \\
\hline & & & sirkulasi udara & & \\
\hline & & & konsentrasi & \multirow{3}{*}{ privasi } & \\
\hline & & & tidak terganggu & & \\
\hline & & & privasi & & \\
\hline
\end{tabular}

(Ivada Ariyani,2020) 


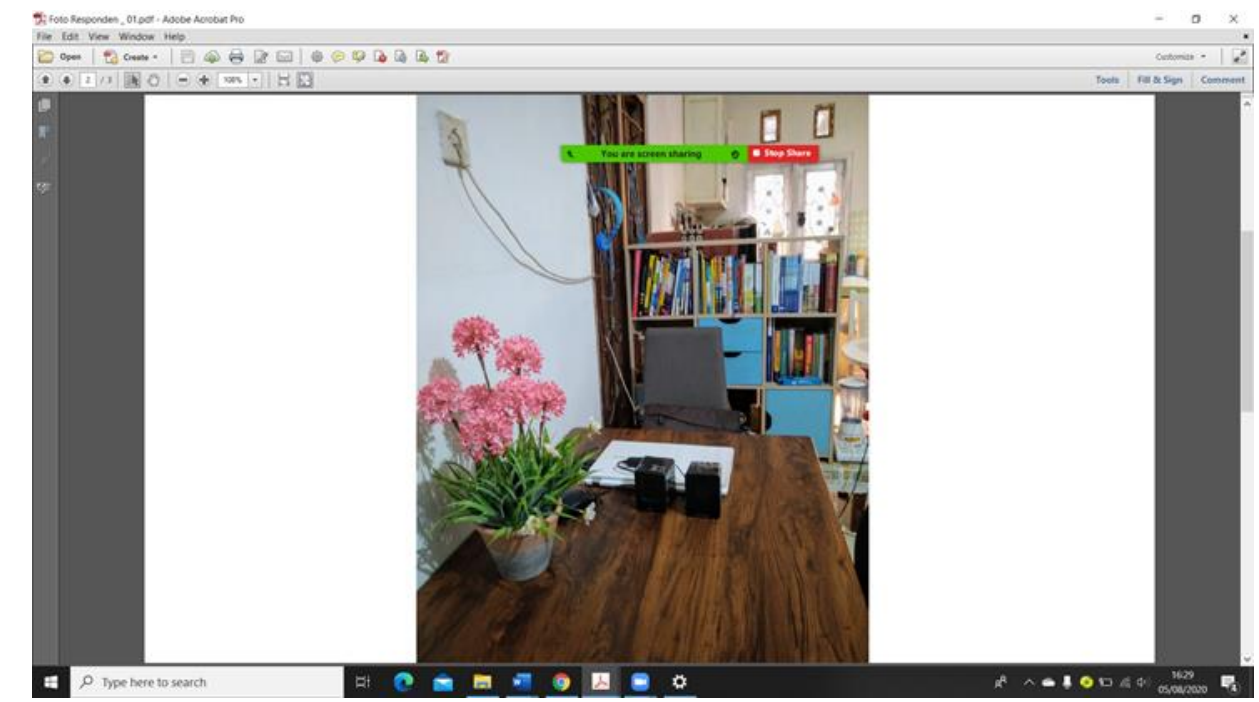

Gambar 1. Area makan Responden 01 yang berubah menjadi area kerja untuk SFH dan WFH setelah 3 bulan pandemi.

(Ivada Ariyani, 2020)

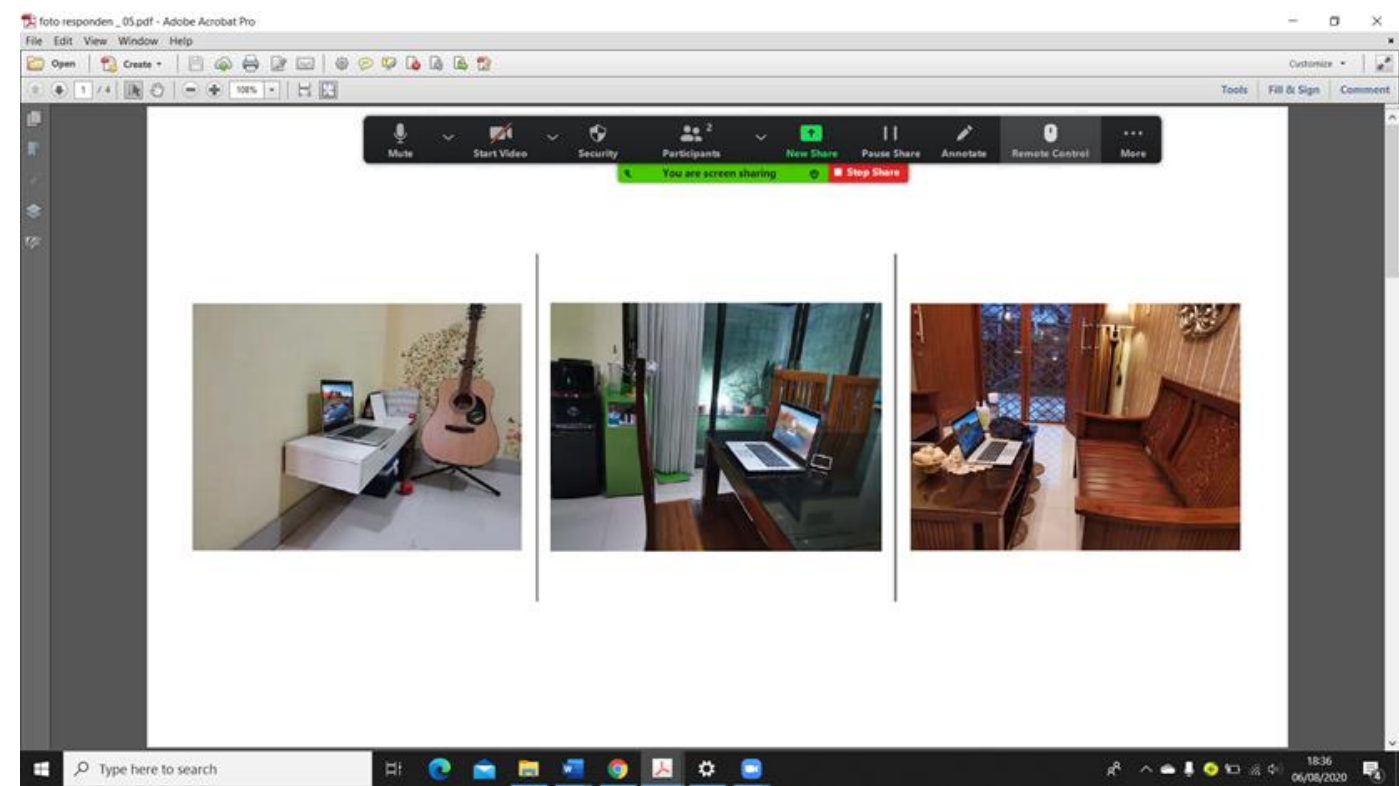

Gambar 2. Meskipun memiliki area khusus untuk bekerja di dalam kamarnya, Responden memilih untuk bekerja dari ruang selasar di bagian samping rumahnya, sembari duduk lesehan.

(Ivada Ariyani, 2020)

\section{Integrasi Fungsi Ruang}

Kebanyakan rumah di Indonesia tidak memiliki area kerja di dalam susunan ruang - ruangnya, sehingga ketika bekerja dari rumah di masa pandemi, orang menempati area dengan fungsi yang berbeda. Sebelum pandemi, dari 9 responden, 4 orang memiliki area khusus untuk bekerja di rumahnya, baik miliknya maupun milik pasangannya. Dari ke-4 ruangan tersebut, 2 diantaranya memiliki konfigurasi ruang yang terpisah secara jelas dari ruang yang lain, dibatasi oleh dinding dan diisi dengan perabot untuk bekerja. Dua ruang kerja yang lain berupa seperangkat meja dan kursi untuk bekerja yang terletak di ruang tidur. Meskipun terdapat ruang khusus kerja di dalam rumahnya, hanya 2 orang yang bekerja dari ruang khusus kerja selama pandemi. Responden yang 
tidak memiliki area khusus kerja, bekerja dari ruang lain dengan aktifitas lain yang terjadi di saat bersamaan.

Ruang majemuk dengan beragam fungsi menjadi area utama para pekerja selama pandemi. Ruang makan, ruang tamu dan ruang tidur adalah ruang - ruang yang sering dipakai para pekerja untuk bekerja dari rumah. Pilihan ruang tersebut beragam, didasarkan atas dinamika aktifitas anggota keluarga yang lain di dalam rumah. Ruang makan seringkali dipilih karena sifat perabotnya yang secara ergonomis mendukung untuk bekerja. Ruang tamu seringkali menjadi alternative pilihan untuk bekerja karena sifatnya yang secara fungsi tidak berlaku selama pandemi, menjadikannya ruang yang relatif senyap dan biasanya memiliki kualitas ruang yang cukup baik. Ada banyak yang menggunakan ruang tidur sebagai area kerja, diantaranya karena sifat ruangnya yang tertutup sehingga memberikan privasi tinggi, ataupun karena kegiatan domestik mengasuh anak memaksanya untuk bekerja dari ruang tidur.

Dari ruang manapun untuk bekerja, ini menjadikan ruang majemuk potensial menjadi area konflik karena distraksi yang terjadi di area ini. Ditambah lagi, karena ruang majemuk ini pada umumnya memiliki konfigurasi ruang yang terbuka, sehingga distraksi dari ruang lain sangat sering terjadi. Ruang makan menjadi area dengan distraksi tinggi, karena umumnya terletak di tengah rumah yang dilewati oleh jalur sirkulasi utama di dalamnya. Hal ini ditambah dengan anak - anak yang bersekolah dari rumah selama pandemi, yang selain menuntut perhatian dalam melaksanakan pembelajaran, juga beraktifitas di seluruh penjuru rumah setiap hari.

Secara umum, pekerja mencari ketenangan serta privasi saat bekerja, terutama ketika harus menghadiri rapat secara daring. Ruang tidur memiliki tingkat privasi yang cukup tinggi serta fitur kedap suara yang lebih baik dari ruang lain yang sering digunakan, meskipun seringkali keluasan tidak mendukung. Ruang tidur juga menjadi pilihan untuk para pekerja yang masih memiliki balita yang harus bekerja sembari mengasuh anak. Meskipun, diakui oleh beberapa responden bahwa ada banyak distraksi di ruang tidur ini diantaranya adalah keinginan untuk tidur. Meskipun, bagi responden lain, ruang tidur justru memberikan kesempatan "break" di tengah - tengah pekerjaan yang dilakukan dari ruang tidur. Sehingga di satu sisi ruang tidur ini menawarkan solusi ruang yang kedap suara, tetapi di sisi lain ruang ini menghadirkan distraksi lain, baik pekerjaan domestik maupun keinginan untuk bersantai di tempat tidur.

Jika melilhat lebih luas dalam skala rumah tinggal, distraksi tidak hanya dilihat dari hubungan antar satu ruang dengan ruang lainnya, tetapi lebih jelas terlihat dalam gambaran situasi bekerja dari rumah dan gabungan kewajiban melakukan pekerjaan domestik. Hampir seluruh responden mengakui distraksi terbesar adalah ketika harus mengerjakan pekerjaan domestik di tengah pekerjaan kantor yang harus mereka selesaikan. Ini juga berlaku bagi responden yang memiliki area khusus untuk bekerja, tetap menjadikan urusan pekerjaan domestik sebagai distraksi terbesar dalam situasi pandemi ini. Sehingga pemisahan ruang kerja yang jelas tidak berpengaruh besar terhadap distraksi pekerjaan domestik selama pandemi. Salah satu responden menyampaikan bahwa jika pandemi berakhir, ia akan memilih tetap bekerja dari rumah, tetapi hanya ketika anak anak pergi ke sekolah, sehingga tidak ada pekerjaan domestik yang harus ia tanggung. Responden lain menyatakan tidak sabar pandemi segera berakhir karena tidak tahan berada di rumah, yang berarti harus menanggung beban pekerjaan domestik yang mengganggu konsentrasinya dalam bekerja. Responden lain yang jadwal pekerjaannya ketat dengan pengawasan ketat pula dari atasannya, harus pula mengerjakan pekerjaan domestik mengajari anaknya membaca dan menulis sembari bekerja. Oleh karena itu ia melekatkan fitur - fitur pekerjaan domestik pada area kerjanya, agar dalam satu waktu ia bisa bekerja sembari mendampingi anaknya belajar. Beragam siasat dilakukan para responden untuk mengatasi distraksi ini, diantaranya adalah dengan berpindah ruang, menciptakan batas ruang, maupun dengan menyusun penjadwalan. 


\section{Kompromi dan Dinamika Penggunaan Ruang}

Terpaksa bekerja dari rumah bukan hanya tentang bagaimana menemukan tempat yang paling nyaman untuk bekerja, tetapi juga tentang bagaimana berusaha mendapatkan satu tempat di antara anggota lain yang juga membutuhkan. Sementara, ruang - ruang yang tersedia tidak memungkinkan bagi seluruh anggota keluarga untuk mendapatkan yang sesuai dengan kebutuhan di waktu dan tempat yang diinginkan. Kompromi terkait waktu dan tempat penggunaan ruang menjadi bagian yang lekat dalam perolehan area untuk bekerja di dalam rumah.

Ada banyak upaya yang dilakukan para pekerja ketika ruang yang tersedia tidak memadai. Ketika konflik "perebutan" ruang menjadi hal yang tidak terelakan, kompromi - kompromi tentang siapa yang berhak memakai ruang apa dan di waktu kapan menjadi salah satu solusi. Strategi dalam menyusun jadwal pemakaian ruang merupakan salah satu yang sering dipakai para pekerja ketika menemui konflik pemakaian ruang. Selama pandemi Responden 01 telah membuat area khusus untuk bekerja sekaligus sebagai ruang bagi anaknya untuk bersekolah dari rumah. Ia merubah fungsi meja makan menjadi meja kerja, sekaligus memindahkan rak buku sebagai latar belakang ketika melakukan pertemuan daring. Namun demikian, Responden 01 lebih banyak memakai ruang tersebut di malam hari dan saat akhir pekan, ketika anak - anaknya tidak memakainya. Ini menunjukkan bahwa ruang tersebut memiliki fungsi yang satu, tetapi digunakan secara bergiliran. Pergantian pengguna ruang juga terjadi pada Responden 06 dan Responden 08, yang harus bergantian menggunakan area kerja beserta peralatannya. Jika Responden 01 harus bergantian dengan anaknya karena alasan personal space yang tidak ia dapatkan, Responden 06 dan Responden 08 harus bergantian ruang dengan anak dan pasangannya karena membutuhkan latar belakang untuk pertemuan daring. Responden 06 harus berpindah sementara dari area kerja ke teras jika suaminya membutuhkan latar belakang untuk pertemuan daring. Demikian pula dengan Responden 08 yang harus berpindah ke studio istrinya demi mendapatkan peralatan berupa PC dan adjustable camera untuk pertemuan daring tertentu.

Ini menunjukkan bahwa ada fleksibilitas sekaligus skala prioritas bagi siapa yang lebih berhak menggunakan ruang tersebut. Responden 01 merasa ia lebih nyaman menyingkir ke ruang tamu maupun ruang tidur, dan membiarkan anak - anaknya belajar dari ruang kerja. Responden 06 akan bergeser ke teras selama $2-3$ jam untuk memberikan suaminya ruang untuk pertemuan daring bersama koleganya. Meskipun ironisnya, sebelum pandemi ruang kerja tersebut adalah milik suaminya, dan kini suaminya hanya memiliki waktu $2-3$ jam jika membutuhkannya. Pola yang mirip terjadi pada Responden 08, yang harus menempati urutan ke-4 jika akan menggunakan studio lukis istrinya. Selama pandemi, ia terpaksa lesehan di depan TV, karena ketika pagi sampai siang hari studio istrinya dipakai anak untuk bersekolah, sementara selain waktu tersebut dipakai istrinya untuk bekerja sebagai arsitek sekaligus pelukis. Responden 08 akan memakai ruangan itu saat larut malam, saat tidak ada lagi yang memakai meja kerja dengan peralatan lengkap itu. Beberapa waktu khusus di siang hari ia bisa memperoleh kemewahan menggunakan meja kerja istrinya ketika ia harus menjadi moderator dalam webinar dimana ia bertanggung jawab sebagai event manager. Responden 09 yang sebelum pandemi telah memiliki ruang kerja khusus, kini juga tetap harus berpindah - pindah ruang ketika membutuhkan privasi untuk melakukan pertemuan daring. Ia mengaku seringkali terganggu dengan kebisingan yang terjadi ketika suaminya yang sebelum pandemi tidak memiliki ruang kerja, harus berdiskusi selama rapat daring.

Penting untuk diamati bahwa keempat responden yang memiliki fleksibilitas dalam berbagi area ini seluruhnya memiliki area khusus untuk bekerja selama pandemi berlangsung. Sementara itu, kelima responden lainnya, yang tidak memiliki area khusus bekerja, tidak mengalami tarik ulur prioritas pengguna ruang kerja. Responden 02, Responden 04, dan Responden 07 yang suaminya juga bekerja dari rumah, tapi tidak memiliki ruang kerja khusus yang layak, masing - masing bekerja berpindah - pindah dari ruang satu ke lainnya. Meskipun Responden 07 lebih establish dan lebih jarang berpindah sejak ia memasukkan meja teras ke dalam kamarnya. Dari sini bisa dilihat bahwa konflik terjadi ketika di dalam rumah tersedia area khusus untuk bekerja. 
Responden yang memiliki dedicated room di rumahnya, selain memiliki potensi konflik perebutan ruang yang lebih banyak juga cenderung berpindah ke lebih banyak ruang. Responden 01, Responden 06 dan Responden 08 berpindah - pindah ke tiga ruangan yang berbeda ketika membutuhkan ruang untuk bekerja. Responden 05, yang memiliki ruang kerja khusus sebelum pandemi, juga berpindah - pindah ke 4 ruangan yang berbeda, meskipun ia tidak mengalami konflik perebutan ruangan karena istrinya bekerja dari kantor. Sementara Responden 02, Responden 03, Responden 04 dan Responden 07 yang tidak memiliki ruang kerja khusus hanya berpindah ke 2 ruang yang berbeda, meskipun tidak dipengaruhi oleh luasan rumah maupun jumlah ruang yang tersedia. Responden 03 yang luas rumahnya $320 \mathrm{~m} 2$ hanya berpindah ke 2 lokasi kerja, ruang makan dan musholla. Demikian juga Responden 09 yang memiliki luas rumah $200 \mathrm{~m} 2$ hanya berpindah dari ruang kerjanya atau ruang tidur anaknya di lantai bawah. Hal ini terkait dengan preferensi ruang kerja yang lebih disukai ketika mereka bekerja dari ruma. Ruang khusus kerja yang sudah ada tersebut dirancang untuk situasi normal ketika bekerja dari rumah adalah sebuah pilihan, atau hanya digunakan sekali - sekali.

\section{Perubahan Fitur Semi Tetap}

Sebelum pandemi, ada 4 responden yang sudah memiliki area khusus bekerja di rumahnya. Kepemilikan area kerja tersebut bervariasi, yaitu 1 orang memiliki area kerja khusus untuk dirinya, 1 orang memiliki area kerja bersama pasangan, dan 2 orang lainnya tidak memiliki ruang kerja secara pribadi, tetapi pasangannya memiliki area khusus untuk bekerja. Selama pandemi, 2 dari responden ini mengalami perubahan layout, 3 orang mengalami penyesuaian pembagian prioritas dan jadwal pemakaian, serta 1 orang justru tidak memakai area kerjanya sama sekali, dan memilih menggunakan ruang lain. Area khusus untuk bekerja yang tercipta selama pandemi ditandai dengan berubahnya lay out ruangan karena keperluan untuk bekerja. Keseluruhan perubahan ini terwujud secara non permanen, berupa perubahan elemen fitur semi tetap. Perubahan ini memiliki variasi yang berbeda - beda, yang bisa ditandai dari berubahnya setting ruang dengan penambahan maupun pengurangan perabot, sampai ke personalisasi ruangan. Perubahan dengan skala yang paling besar adalah dengan menciptakan ruang kerja baru melalui alih fungsi ruang yang sudah ada. Jenis perubahan selanjutnya adalah dengan menambahkan maupun mengurangi perabot dalam satu ruangan, serta perubahan dengan mengubah tatanan (layout) perabot. Penciptaan area kerja yang terintegrasi dengan ruangan lain pada umumnya mengalami personalisasi ataupun pembatasan teritori yang bersifat dekoratif.

Ruang kerja baru yang tercipta selama pandemi merupakan ruang kerja non permanen yang disusun atas perabot yang sudah ada sebelumnya. Penyusunan secara sederhana ini juga diikuti dengan personalisasi ruangan untuk menandai kepemilikan area. Responden 06 yang mengakuisisi ruang kerja suaminya memasang wallboard di samping mejanya dan mengisinya dengan berbagai jadwal dan post it terkait pekerjaannya, agar terasa seperti area kerja di kantor. Ia juga menciptakan personalisasi di area ini dengan memasang background untuk rapat daring, dan mengisinya dengan foto - foto anaknya dan dekorasi tumbuhan artifisial. Responden 01 mengisi rak buku sebagai latar belakang rapat daring dengan buku - buku yang memberikan citra persona diri terkait profesinya. Ia juga menambahkan vas bunga pada meja kerjanya sebagai tambahan elemen dekoratif.

Personalisasi sebagai upaya untuk menciptakan area nyaman selama bekerja di rumah tidak berlaku bagi responden yang tidak menyukai bekerja dari rumah. Responden 07 sama sekali menghindari upaya untuk membuat area kerjanya menjadi nyaman. Ia melanggengkan rasa tidak nyamannya itu untuk memelihara rasa ingin bekerja dari kantor agar terhindar dari pekerjaan domestik yang menganggu konsentrasinya dalam bekerja. Sehingga upaya yang dilakukan untuk menciptakan area kerja juga hanya dengan memindahkan meja teras berdiameter $70 \mathrm{~cm}$ ke dalam kamarnya. Perpindahan area bekerja, dalam beberapa kasus juga berarti perpindahan perabot. Hal ini terutama terjadi pada responden yang tidak memiliki area khusus bekerja, dan harus berpindah - pindah ruang sesuai dengan kebutuhan kerjanya saat itu, atau karena tuntutan pekerjaan domestik yang harus dilakukannya. Hampir separuh dari responden duduk di lantai atau lesehan 
ketika bekerja dari rumah. Dua diantaranya berpindah dengan sangat dinamis, dari ruang satu ke ruang lainnya, yang diikuti dengan berpindahnya perabot berupa meja lipat untuk menempatkan laptop dimanapun dia bekerja. Ini juga berlaku bagi mereka yang lebih memilih area kerja karena preferensi suasana yang mendukung pekerjaan, dibandingkan dengan memilih ruang yang memiliki perabot lebih layak untuk mendukung bekerja.

\section{Background Sebagai Penghubung Ruang Sosial}

Latar belakang saat berlangsung pertemuan daring menjadi pertimbangan seseorang melakukan perubahan, baik berpindah ruang maupun merubah setting ruang. Responden 01, Responden 03 dan Responden 06 secara sadar melakukan perubahan pada ruangannya untuk mendapatkan latar yang merepresentasikan mereka di hadapan publik sosialnya. Responden 01 dan Responden 03 melakukan perubahan setting latar belakang sebagai upaya untuk memberikan citra yang dianggap layak dari seseorang yang memiliki status tertentu terhadap sub - ordinatnya. Responden 01 ingin memberikan gambaran sebagai seorang dosen yang rajin membaca buku terhadap mahasiswanya dengan memindahkan rak buku sebagai latarnya, sementara Responden 03 sebagai seorang direktur ingin dilihat sebagai seseorang yang religius dengan menempatkan hiasan dinding bernuansa religi. Keduanya memiliki tujuan sama, yaitu ingin memberikan citra teladan bagi sub ordinatnya.

Berkebalikan dengan Responden 01 dan Responden 03, Responden 06 mendekorasi dinding karena ingin menampilkan nuansa "rumah" ketika harus rapat daring dengan atasannya. "Terkadang saat rapat, si boss besar akan memintaku untuk mengaktifkan video, untuk melihat apakah aku ada di rumah atau tidak". Kontrol manajerial membuat Responden 06 harus menyesuaikan setting background agar meyakinkan atasannya bahwa ia menjalankan tugas selama bekerja dari rumah. Ketiga responden menggunakan latar belakang saat pertemuan daring dengan berada di ruang yang privat, untuk merepresentasikan individu ke dalam ruang publik secara maya. Responden akan mencari waktu yang tepat dimana ia bisa berada di area kerja dengan membatasi teritori dan menciptakan personal space, untuk bisa hadir di ruang publik di depan banyak audiens. Responden 01 akan mencari waktu dimana anak - anak tidak ada di sekitar ruangan sementara Responden 06 akan menutup pintu area kerjanya. Ini menciptakan sesuatu yang paradoks, dimana ia akan berada di situasi privat yang nyata untuk sekaligus berada di ruang maya yang publik. Kesadaran akan kehadiran ruang privat di wilayah publik juga disadari oleh Responden 09 yang meskipun memiliki area kerja yang representatif memilih kamar anaknya untuk melakukan pertemuan daring, karena merasa tidak nyaman berbagi layar berisi interior rumahnya kepada sub - ordinatnya. Sebaliknya, ia akan berbagi ruang privatnya dengan kolega dekatnya saat rapat daring terbatas. Ini menunjukkan bahwa untuk ruang privat terbuka bagi seseorang yang secara pribadi memiliki hubungan yang lebih dekat, sementara bagi orang yang tidak terlalu dekat akan diterima dengan gambaran yang terbatas.

Dengan demikian dapat dilihat bahwa layar saat pertemuan daring dalam dunia nyata berlaku seperti ruang tamu yang di suatu titik merepresentasikan bagaimana tuan rumah akan memperlakukan tamunya. Responden 01, Responden 03 dan Responden 06 mempersiapkan ruang tamunya sebagai ruang publik dari bagian rumahnya untuk menerima tamu, sehingga yang seringkali ditemui adalah ruang tamu akan ditata untuk menyambut tamu. Ini juga berlaku bagi Responden 09 yang membatasi siapa saja yang boleh masuk ke dalam ruang tamunya. Responden 05 dan Responden 08 memilih menggunakan virtual screen resmi kantornya dalam pertemuan daring. Responden 05 menggunakannya ketika mengadakan pertemuan formal dimana dia berlaku sebagai reviewer. Demikian pula Responden 08, dia akan menggunakan company virtual screen saat dia menjadi moderator dalam sebuah webinar. Dalam situasi yang lebih informal dimana Responden 05 bertemu virtual dengan koleganya, ia akan berpindah ruang yang memiliki dekorasi dinding sebagai latar belakangnya. Demikian juga Responden 08 akan melakukan hal yang sama, ia akan memilih ruang yang memiliki latar belakang salah satu jendela rumahnya yang memiliki tirai. 
Responden 01 dan Responden 04, yang keduanya tidak memilki area khusus untuk bekerja memilih berlatar belakang dinding polos saat pertemuan daring. Responden 04 tidak pernah lagi menggunakan virtual background karena tidak nyaman dengan hasil tampilan yang ada di layarnya. Demikian pula Responden 07, yang meskipun menurut teman - temannya memiliki dapur yang instagramable memilih menggunakan background dinding polos ruangannya.

\section{Preferensi Ruang Kerja Sementara}

Tema preferensi ruang kerja sementara ini muncul untuk menjawab pertanyaan penelitian mengenai ruang kerja seperti apa yang diciptakan saat pandemi. Terlepas dari adanya responden yang telah memiliki area kerja sebelum pandemi, ruang kerja yang terjadi selama pandemi dalam penelitian ini disebut sebagai ruang kerja sementara. Hal ini didasari atas respon bahwa 3 orang responden menyatakan secara lugas bahwa situasi pandemi ini adalah sementara, sehingga tidak perlu untuk menata secara khusus area kerja untuk WFH. Responden 02, 03 dan 04 bekerja secara berpindah - pindah dari satu ruang ke ruang yang lain dengan membawa laptop beserta perangkat meja lipat. Responden 07 memindahkan secara tetap meja teras ke dalam ruang tidur sebagai pojok kerjanya yang baru selama pandemi. Responden 05 meskipun sudah memiliki area khusus kerja di ruang tidurnya yang hanya ia gunakan selama 2 minggu, memilih untuk bekerja di bagian lorong di rumahnya. Dari seluruh responden tersebut, semua menyebutkan "(udara) segar" sebagai alasan mendiami ruang tertentu. Bahkan responden 05 yang telah memiliki area khusus kerja memilih duduk lesehan di lorong untuk mendapatkan udara yang segar. Kata "pemandangan" (mengacu ke halaman atau kebun) juga muncul beberapa kali di dalam wawancara mengenai preferensi ruangan untuk WFH, setidaknya disebutkan oleh 4 orang responden. Kata yang memiliki asosiasi dengan kata "break" dan "refreshing" juga beberapa kali muncul untuk menjawab preferensi ruangan untuk bekerja.

Ruang - ruang yang menyediakan udara segar, pemandangan hijau serta memberi kesempatan para responden untuk "break" dan "refreshing" ini bahkan mengalahkan kebutuhan mereka atas aspek fungsional, seperti ergonomi. Ini terlihat jelas pada Responden 05 yang memilih duduk lesehan di lorong, daripada duduk di meja kerja di ruang tidurnya. Demikian juga yang terjadi pada Responden 03 yang memiliki banyak ruang di rumahnya yang seluas $320 \mathrm{~m} 2$, dan bisa memilih duduk dengan baik, tetapi memilih duduk lesehan untuk mendapatkan udara segar dan suasana "refreshing" di dekat kolam. Responden 02 dan 04 yang memiliki pola kerja berpindah - pindah dari $2-3$ pilihan ruang, keduanya memilih ruang yang memiliki akses udara segar, pemandangan hijau dari halaman, serta "tidak membosankan", meskipun dari keseluruhan pilihan ruangnya mereka tetap duduk secara lesehan. Responden 07 yang berpindah dari meja makan ke meja teras di ruang tidur dengan kualitas ergonomi yang lebih rendah juga menyatakan bahwa pojok kerja ini memberikan kesempatan "break" dan pemandangan halaman yang menyenangkan di sela - sela kerja.

\section{Pembahasan}

Pada hari - hari pertama diberlakukannya bekerja dari rumah, respon para pekerja pada umumnya langsung bekerja pada ruang - ruang dan perabot yang tersedia saat itu. Secara umum, 2 minggu pertama diberlakukannya WFH, mereka bekerja dari ruang yang paling mudah memberikan akses bagi terlaksananya pekerjaan dengan lancar. Ini adalah saat penyesuaian, dimana koordinasi awal para pekerja dengan kantor dilakukan melalui sistem daring. Hampir semua responden menyatakan, di awal diberlakukannya sistem bekerja dari rumah, pembicaraan melalui telepon dan aplikasi chat lebih banyak digunakan. Situasi saat itu masih berada dalam kondisi saat tiba - tiba semua dilarang datang ke kantor, dan bekerja dari rumah. 2 minggu pertama, situasi bekerja dari rumah merupakan situasi darurat. Pilihannya adalah, bekerja dari ruang tamu dengan lesehan, berpindah - pindah ruang untuk mencari titik yang memiliki jaringan internet yang paling bagus, 
berbagi ruang kerja dengan pasangan, bekerja dalam satu meja makan dengan seluruh anggota keluarga, ataupun berpindah - pindah ruangan sesuai preferensi tertentu.

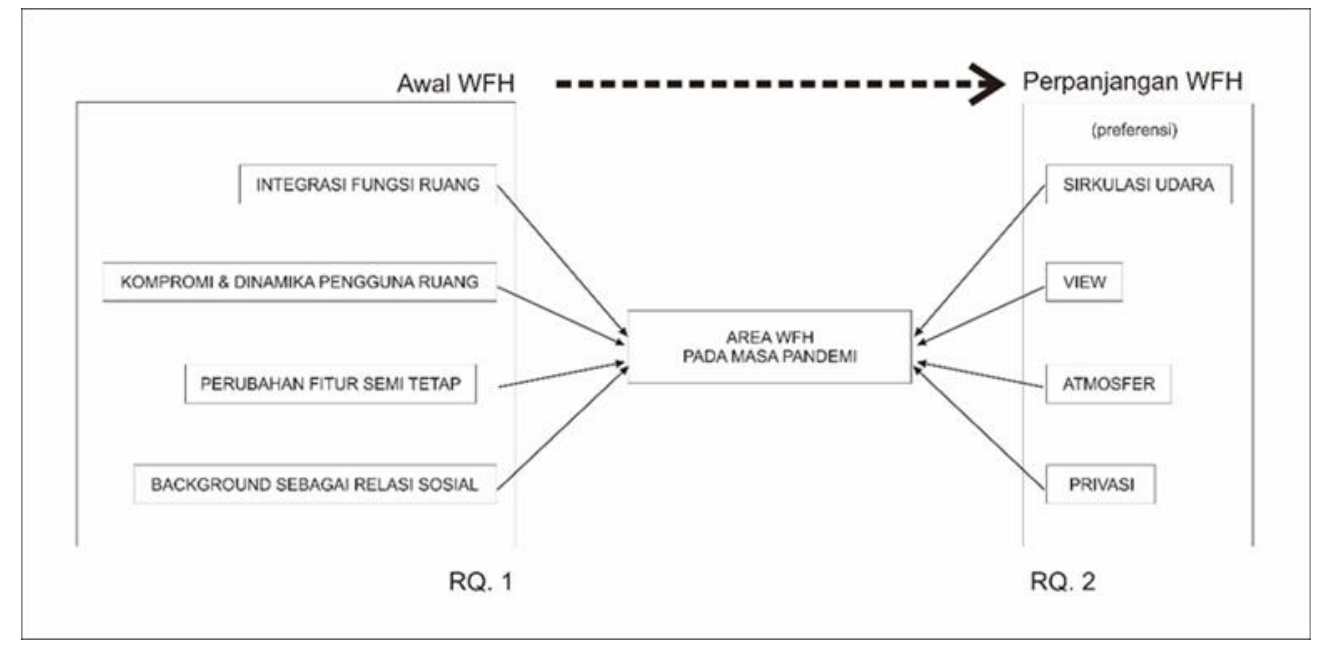

Gambar 3. Penyesuaian yang terjadi pada area WFH di masa pandemi. (Ivada Ariyani,2020)

Diperlukan waktu sekitar dua minggu bagi para responden untuk mulai mencari area yang lebih sesuai dengan kebutuhan mereka. Setelah selama periode awal bekerja dari rumah, para pekerja mulai menyesuaikan kebutuhannya dengan ruang yang mereka tempati. Meskipun, ada sebagian kecil yang tiga bulan kemudian baru menyesuaikan area kerjanya. Beberapa di antaranya adalah, beralih lokasi bekerja, alih fungsi ruang, berbagi kepemilikan ruang, serta mengambil alih kepemilikan ruang.

Saat awal diberlakukannya WFH, ada empat tema hal besar yang muncul dalam analisis hasil wawancara, yang sudah dibahas sebelumnya. Integrasi antara lebih dari satu fungsi dalam ruang menjadi hal yang sangat umum terjadi, mengingat rumah di Indonesia pada umumnya tidak memiliki ruang kerja. Integrasi fungsi ruang ini menciptakan ruang majemuk yang pada banyak titik menimbulkan friksi antar anggota keluarga. Terbatasnya ruangan tidak sebanding dengan aktifitas tambahan yang dipaksa harus berlangsung setiap hari selama pandemi menuntut adanya kompromi antar anggota keluarga. Hal ini berbeda - beda di antara tiap keluarga. Kompromi, penjadwalan, dan prioritas menjadi salah satu cara untuk setiap orang dapat melakukan pekerjaannya dengan dukungan perabot, ruang, maupun peralatan yang optimal di saat bekerja dari rumah. Menariknya, tarik ulur antar pengguna tentang siapa dan kapan menggunakan ruang khusus kerja tidak terjadi di dalam rumah tinggal yang tidak memiliki ruang khusus kerja. Tentu saja karena tidak ada hal yang diperebutkan. Tetapi ini menjadi menarik, karena friksi yang terjadi lebih sedikit. Para pekerja yang di rumahnya tidak ada ruang khusus bekerja sebelum pandemi maupun selama pandemi berlangsung, menempati ruang yang ada dengan preferensi masing masing. Menariknya lagi, para pekerja yang sebelum pandemi sudah memiliki ruang khusus bekerja, tetap berpindah - pindah dalam melakukan pekerjaannya sehari - hari. Ini terjadi bahkan pada pekerja yang ruang kerjanya cukup representatif dan dilengkapi dengan perabot dan peralatan kerja. Alasan di sebaliknya inilah yang kemudian akan menjadi pemicu mengenai ruang kerja seperti apa yang mereka butuhkan ketika terpaksa harus bekerja dari rumah selama pandemi.

Berpindahnya pekerja dari ruang satu ke ruang yang lain didasarkan atas kebutuhan khusus saat berlangsungnya pekerjaan. Seringkali diantaranya adalah kebutuhan untuk berkonsentrasi pada pekerjaan sehingga menghindari distraksi, ruang yang memberikan privasi tinggi terutama saat berlangsungnya rapat daring, serta kualitas ruang tertentu. Point ketiga sangat menarik, terutama 
karena ini muncul sebagai preferensi alasan berpindahnya mereka ke sebuah ruang tertentu. Pemandangan, udara segar, sesuatu yang tidak membosankan sangat sering muncul untuk menjadi alasan mereka untuk menempati ruang. Meskipun, alasan teknis tentang konsentrasi dan privasi menjadi utama ketika mereka harus melakukan tugas tertentu. Tetapi secara umum, dari banyak ruangan yang ada di rumah mereka, ruang dengan kualitas tata kondisional serta atmosfer positive menjadi pilihan. Ini terkait dengan alasan bahwa bekerja dari rumah bukan pilihan yang secara sadar dilakukan dengan sukarela, tetapi karena situasi pandemi yang harus memaksa pekerja untuk bekerja dari rumah. Sementara, fasilitas, ruang, peralatan, situasi dan kondisi rumah tinggal tidak dipersiapkan untuk menjalankan itu semua dengan baik.

\section{Simpulan}

Penelitian kualitatif ini telah mampu menjawab pertanyaan penelitian tentang bagaimana penyesuaian yang dilakukan para pekerja terhadap setting ruang di dalam rumah untuk mengakomodasi kebutuhan work from home. Dalam situasi pandemi di awal penerapan WFH, para pekerja cenderung menciptakan ruang - ruang majemuk dengan mengintegrasikan beragam fungsi dalam satu ruang. Ini terjadi karena pada umumnya rumah di Indonesia tidak memiliki ruang khusus untuk bekerja. Dengan adanya integrasi fungsi ruang, timbul konflik dan friksi antar pengguna ruang sehingga terjadi kompromi atas dinamika pengguna ruang di dalam satu rumah tinggal. Ditemukan juga bahwa terjadi perubahan setting ruang dalam berbagai tingkatan, yang secara umum dilakukan pada perubahan fitur semi tetap. Perubahan setting maupun dinamika pergerakan penghuni di dalam rumah tinggal juga dipengaruhi oleh kebutuhan citra ruang dalam menjalin relasi sosial melalui daring di saat pandemi.

Penelitian ini juga telah menjawab pertanyaan penelitian tentang setting ruang seperti apa yang mampu mengakomodir kegiatan WFH dengan optimal di situasi darurat. Pertanyaan ini terjawab dengan melihat situasi perpanjangan bekerja dari rumah pada seluruh responden / pekerja. Secara umum, hal paling dibutuhkan dalam bekerja dari rumah di situasi krisis ini adalah ketiadaan beragam gangguan/ distraksi. Namun seiring waktu, hal yang ditengarai penting bagi kelangsungan bekerja dari rumah adalah atmosfer rumah tinggal yang mendukung. Sirkulasi udara alami, akses terhadap view di luar serta atmosfer yang membebaskan dari rasa bosan dan perasaan terkungkung adalah faktor - faktor yang sangat penting dalam menyediakan ruang kerja di rumah di saat pandemi.

Kontribusi penelitian ini adalah untuk memberikan gambaran secara umum tentang situasi rumah tinggal, khususnya setting ruang yang terjadi beserta permasalahan yang timbul, ketika para pekerja harus bekerja dari rumah dalam situasi krisis. Lebih dari itu, temuan tentang gambaran ruang yang mampu mengakomodir kegiatan WFH dengan optimal dapat digunakan untuk membantu masyarakat umum untuk sedikit banyak menerapkannya di dalam rumah tinggal mereka. Sebagai sebuah studi eksplorasi, penelitian ini memiliki keterbatasan berupa jumlah responden yang tidak terlalu banyak. Untuk itu, penelitian selanjutnya dapat dilakukan dengan sampel data yang lebih besar serta skala penelitian yang lebih luas. Hal kedua, penelitian selanjutnya perlu memberikan rekomendasi yang lebih praktikal dan mudah diterapkan ke dalam ruang - ruang kerja di dalam rumah tinggal, untuk dapat membantu pekerja bekerja dari rumah dengan lebih baik. 


\section{Daftar Pustaka}

Anderson, M., Bechhofer, F. and Gershuny, J. (eds). 1994. The Social and Political Economy of the Household, Oxford: Oxford University Press.

Benczes, R. 2006. Creative compounding in English. Amsterdam and Philadelphia: John Benjamins Publishing Company.

Budhiekusuma, Noor Patria, Hadi, Sasongko Pramono, dan Winarno, Wing Wahyu, 2017. "Peluang Pemanfaatan Telecommuting dalam Pemerintahan di Indonesia", Vol. 2 No. 2, Oktober 2017, Jurnal Pekommas.

C. Moorman dan A.S. Miner. 1998. "Organizational improvisation and organizational memory”. $23: 698-723$. The Academy of Management Review.

Felstead, A. and Jewson, N., 2000. In work, at home: Towards an understanding of homeworking. Psychology Press.

Higa, Kunihiko dan Wijayanayake, Janaka, 1998. Telework in Japan: Perception and Implementation. Tokyo Institute of Technology.

Jackson, Paul J. dan Wielen, Jos M. Van Der ed., 1998. Teleworking: International Perspectives. From Telecommuting to the Virtual Organisation. Routledge, London and New York.

Kendra, J. and Wachtendorf, T. 2007. "Improvisation, Creativity, and the Art of Emergency Management" dalam H. Durmaz et al. (Eds.). Understanding and Responding to Terrorism. IOS Press.

Korte, W., 1996. The Social Implications of Telework. Penetration, Potential and Practice of Telework as well as Labour Law, Social Security, Occupational Health and Safety Issues in Telework and Possible Actions. Conference Document, 22 April 1996, Brussels.

Mungkasa, Oswar. 2020. "Bekerja Jarak Jauh (Telecommuting): Konsep, Penerapan dan Pembelajaran”. Bappenas Working Papers Volume III No. 1 - Maret 2020, Jakarta: Kementerian Perencanaan Pemban Responden 05an Nasional/ Bappenas - Indonesia.

Mustajab, Duta, Azies Bauw, Abdul Rasyid, Andri Irawan, Muhammad Aldrin Akbar, and Muhammad Amin Hamid. 2020. "Working from Home Phenomenon as an Effort to Prevent COVID-19 Attacks and Its Impacts on Work Productivity." 4 (1), pp.13-21, The International Journal of Applied Business.

Ohio University, 2015. Telecommuting Can Save Business Money. Online Master of Business Administration. https://onlinemasters.ohio.edu/blog/how-telecommuting-can-savebusinesses-money/ diakses pada 9 Januari 2020

Rapoport, Amos. 1990. "Systems of activities and systems of settings" dalam Kent, Susan (Ed.). Domestic Architecture and The Use of Space: An Interdisciplinary Cross-Cultural Study. New York: Cambridge University Press.

Weick, K.E. 1996. Drop your tools: An allegory for organizational studies. 41/2, 301-313. Administrative Science Quarterly. 